preganacy, where Inbeur has net immedialely superveacd, the prognesis shoukl bo vely inich regulated by the stalc of the founs; for if it be proved by the stetho. scepe itiat the child is ative, we may venture to hope that gestation will go en tindisturbed (unless the convulsions recur); whereas, if tho eliild lins been destroyed, its expulsien will take place, mest probably, in tell or feurteea days from the date of the cenvulsive altack.

9. No certain cenclusien regarding the state of the fretus can bo drawa from the charaoters of the plicental senfllet.

10. In cases of fleoting befere delivery, observation of the placeatal brit may supply useful diagnostic in formation, by pointing ont the part ol the utema te which the after-birth is nttached, nad thereby showing whether the hemerrliage be aceidental or unavoidable.

11. Auseultation of the heart ia still-bern children moro accurately acquaints us with the state of the child's vital powers, than aay other souree of information, and is, therefore, well desorving of employment in all such cases.

63. Spontaneous Rupture of the Uterus from thimness of the Parieles.-Mrs. _- was taken in a labeur, I believe at her full lime. 'Ilse labenr nppenred to be going on naturally, when soddenly symploms of greal depression oceurred, accoinpanied witl vemiting nut extremo tenderness of the abdomen, and the patient sumk rapidly, dying a few hours afler the first accession of the dangerous sj'mptoms. On examination after death, there did not appear to be nuy malfermatien of the pelvis, or disproportienale sizo of tho cliild. She liad bernc several childrea, aad her tabeurs hind been natural, though rather lingering. 'Tle cause of lie rapture appeared to be, that one-lialf of tho ulcrus, as the foins incrensed in size, merely dilated, but did not increase in thicknces as it slıould have dono, se that whilst the cavity of the uicrus was of the size it onglit to have been in pregnancy, the substance of the walls of one.lialf was litle llicker llian brewn paper, the substance of the other half beiag of the proper thickness. It appenred, therefere, whicn labeur camo en, that the part of tho utcius which was thus prelernaturally alien. ated liad been uaablo to resist the toasion, and laal given way. Nothiug was diseevered to acceunt for this want of nutritioa. The paticnt had genernlly eajoyed telerable liealth. The true natare of tho ease, thongh suspected, was net ascer. lained till after deall, - Loml. Mlcl. Gaz., Oct. 1847.

61. A ncw method of bringing on Premature Jelivery.-The German jeurnals cen. tain the accenal of a new method of indueing prematnre labour, where required, as praclised by M.Cenns, of Hamburg. Thit physieian has bcen lecl to employ the subjoined melhed from noticing the power of injectieas inte the uterus, in develeping centractiens of tliat organ; nud as the pregnant uterns is in a cendition apt to contract, lic theugltt injections miglt be eflicecionsly used, and that without dinger, te bring on delivery, in these eases where it is necessary tho foctus sheuld be expelled betorc lie fuill ierm of pregnaney.

la the earrying out of lis plnn, M. Colsen has uscd a eommon small syringe, holding from one eunco and a half to twe ounces of lignid, and farmisled with a eamula eight or niae iaches ia leagth, about one-eighth of an inch in diameter al its extremity, and curved like a female eathetor. 'Jhe patieat is placed on her back, and the pelvis slightly raised. 'Two fingers are then passed inte the vaginu as far as the pesterior lip of the uterus, in order te gnide the canula, which is introduced between the aaterier wall of the uterns and the ovum. 'The free extremily of the syringe is now lewered se as to allow the eammla to glicle under the pubic areh until it penotrates about two iaches into the wterus, and at this point the injection is begun. 'The fluid is injerted slowly anc geally, laking earo se to raise the syringe that the extremity of the easula may net nbut agaiast the wall of the uterus, and to vary its direction whenover any obstacle occurs to the escapo of the liquid; the syriage is also willudrawn by degrees. Ten minutes afterwards, the woman may get up and walk abent. If at the end of six hours there is no sign of approaching labesr, the operation may be repeated.

Dr. Colıen lias used for injectien tar-water, which fluid he hns also employed to diminish exeessive secretien from the mterime surfnce. The auther gives a case in which he reserted to this plan of injeeting with suceess, it was one of 
eontracted pelvis-eontracted in all its diameturs, and lardly equnl in sizo to thit of a young girl Iwelve years old. 'This woman's first delivery was arcomplished by craniotomy and tho forcejs; and $\mathrm{M}$. Cuhen alvised, in the easo ol a second presnancy, to induco premature labour, which was accorlingly dono by him, whon the woman was tho noxt time with child, according to the precediog plas', and aller two injectiens wore performed, at an intorval of six houre. The child was bern footling, and survived; nud tho mother had a rery favourable convaleseence.

Tho preceding plan appears to possess the advantage of ioluciog labour so gracturilly as to allow of the dilatation of tho os uteri before the bursting of the membrantes, and tho forcing arainet it of tho harder presenting part. Most of the mothods nuw employed to bring on labonr aro apt to etansu very sudclen and violent contractions, with the almost immediate rnpturo of tho menbranes, which is a disutvantage; and therefure, if no oljection seem tu attach to the preceeding of M. Cohen, it would bo preferable. It has this disalvaniage, that it is not ro simple of executien as tho inere introduction of a callieter fu rnpture the weinbranes, or to soparato thoin from tho walls of tho utorus.-Lancel, Sept. 25, 1847.

\section{ANASTIETIC AGENTS.}

[In our last number wo presented a fair and unbjassed report of tho then existiug stato of knowlelgo in regard to tho use of ethor as in mons of munulling paii, in order to enablo the reader to judgo how far thu uso of this agent was salo or oxpodiert. Wo slall now, in furihorance of tho same object, endenvour to bring togetler tho prominent facts and opinions whiuh havo sinco been brouglit forwnrd. Previously, lowever, to doing this, wo must givo an aceount of a new anæsthutie agent, very reconlly proposed by Prof. Simpson, of Elinburgl, as a oubstitute for tho sulphurie ethor, and which is now lauded as very supporior to tho lattur it severnl respects. Tho discovery, in this country, of tho property of ethor of anmulting pain, has given an impulso to investigntion in that direction, nud otler articlus inay be liereafter discovored, possessiog nnestlietic powers superior to any yot known. Even, however, should this happou and tho ether be ontirely superseded by another more eflicient nud safor agent, still, a lnrgo portion of lonour must bu awarded to our countrymen, for having stricken out tho path which has lud to the diecovery:]

65. Accont of a new Ancesthetic Agent, as a Substinte for Sulphuric Fther in Surgery and Mlidwifery. By J. Y. Simson, M. D., li. M.S. L., I'rof. Mid. Univ. Bilinburgli, \&e. (Communicated to tho Med.-Chirurg. Soc. of Kdinburgh, Nov. 10, 1847) [Just as we wero closing this number wo received from the nuthior a eopy of the following paper, whielı we husten to prosent entire to our readors.]

Froun the time at which I first saw ether-inhalation snccessfully practised in January last, 1 havo had tho convietion impressed npon my minil, that wo would ultimately find that other therapuntie agents wero eapablo of being introduced with equnl raplitity and success into tho system, through the samo oxtensive and powertul channel uf pulmonary alsorption. In somo observations, which 1 wrote and published in licuruary last, relativo to the inhnlation of sulpharic ether in mid wilery, I stated that, in several obstetric enses. I had used orgot of rye in this way, aloug with ether.- (See Monthly Joumal of Medicul Science, pp. 724 anit 795. Case of Successful Inhalation of Opium, to Arrost tho Vomiting of Preguancy.) .

With varieus professional frieuds, moro conversant with clemistry than $l$ am, I have, sinco that time, taken opportunities of talking over tho iclea which 1 entertivined of tho probable existence or discovery of new therapeutic ngents, eapable of being introduced into the system by rospiration, and the possibility of producing for inlanlatiun vaporizable or volalile preparatious of some of our more active anil oll establisled medicines: and I have lad, during the summer and antumo, othereai tinctures, \&c., of several potont drugs, manufnctured for ine, for experiinunt, by Messrs. Duncau, Flockluurl, \& Co., the excollont chemists and druggists of this city.

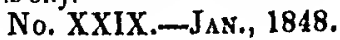

